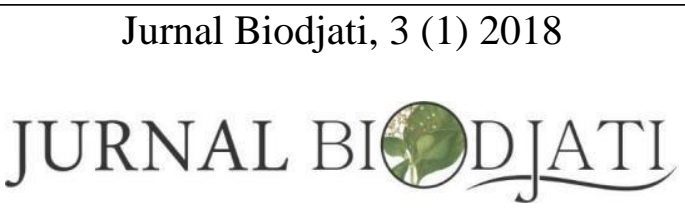

http://journal.uinsgd.ac.id/index.php/biodjati

\title{
PURIFICATION AND CHARACTERIZATION OF CELLULASE OF MOLD ISOLATED FROM VERMICOMPOSTING PROCESS OF PALM OIL EMPTY FRUIT BUNCHES
}

\author{
Rosita Fitrah Dewi ${ }^{1}$, Kahar Muzakhar ${ }^{2^{*}}$ \\ ${ }^{1}$ Program Studi Tadris Biologi, Institut Agama Islam Negeri Jember \\ ${ }^{2}$ Jurusan Biologi, FMIPA Universitas Jember
}

\begin{tabular}{l} 
Received :31March 2018 \\
Accepted : 27 May 2018 \\
Publish : 31 May 2018 \\
\hline${ }^{1}$ Jl. Mataram No. 1, Mangli, \\
Kabupaten Jember, Jawa Timur, \\
Indonesia \\
${ }^{2}$ Jl. Kalimantan 37 Kampus Te- \\
galboto Jember, Jawa Timur, \\
Indonesia \\
e-mail: \\
${ }^{2}$ kaharmzk@unej.ac.id
\end{tabular}

e-ISSN : 2541-4208

p-ISSN : 2548-1606

\begin{abstract}
Abstrak. In previous investigation of vermicomposting process of palm oil empty fruit bunches, five cellulase-producing microorganisms had been isolated. An isolated VTMI identified as Aspergillus sp. as a cellulase producing mold, and proven produced extracellular cellulase in solid state fermentation of palm oil empty fruit bunches. The obtaining crude cellulase was purified to homogeneity by ammonium sulfate precipitation, gel filtration on Sephadex G-100 chromatography, and finally purified on ion exchange chromatography on DEAE Cellulofine A-500. The yield and purification fold were $12.89 \%$ and 107.50 , respectively. The purified cellulase was easily released glucose when 5\% CMC applied as substrate, as shown by TLC analysis. The purified cellulase had an optimal $\mathrm{pH}$ and temperature at 4.0 and $45^{\circ} \mathrm{C}$, and was stable at $\mathrm{pH} \mathrm{3-7}$ and $30-50^{\circ} \mathrm{C}$, respectively.
\end{abstract}

Key words: extracellular enzyme, cellulase, purification, VTM 1 (Aspergillus sp.).

\section{Cite}

Dewi, R. F. \& Muzakhar, K. (2018). Purification and Characterization of Cellulase of Mold Isolated from Vermicomposting Process of Palm Oil Empty Fruit Bunches. Jurnal Biodjati, 3 (1), 1-7.

\section{INTRODUCTION}

Cellulase is an essential enzyme for industry which categorized as 1,4- $\beta$-D-glucan selobiohidrolase (exoglucanase), 1,4- $\beta$-Dglucan 4-glukanohidrolase (endoglucanase), and $\beta$-glucoside-glukohidrolase or $\beta$-Dglucosidase (cellobiase). $\beta$-D-glucosidase itself synthesize by specific gene in microorganism (Fitri et al., 2017), thus the characteristic would be unique for each species. Cellulase hydrolyzes cellulose complex polysaccharides to simple polysaccharide form, which consist of oligo and sugar as monomers, called glu- cose (Kim \& Kim, 1995; Muzakhar et al., 2015; Muzakhar et al., 2017). Cellulose is composed of D-glucose which are bound by ties of $\beta(1 \rightarrow 4)$. Cellulase is produced by cellulolytic microorganisms, such as fungi, bacteria and actinomycetes (Ariffinet. al, 2006; Kanti, 2005). The application of cellulase in the industry is more desirable than using synthetic chemicals because high purity level of products that produced, do not cause corrosion, resulting in higher yields and do not require a lot of energy in the process of hydrolysis (Bakare et al., 2005; Masfufatun, 2009). 


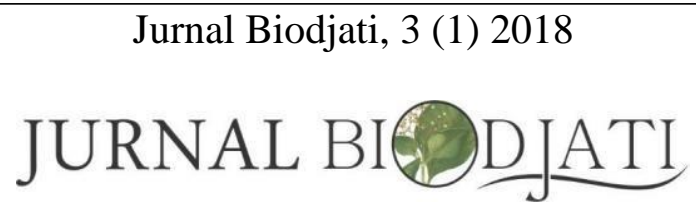

http://journal.uinsgd.ac.id/index.php/biodjati

A huge amount of palm oil empty fruit bunches (POEFB) produced during oil palm production and about $40 \%$ of POEFB material is consist of cellulose fiber (Hayati, 2010). Decomposition of palm oil empty fruit bunches are naturally very slow, thus it is necessary to develop alternative method to degrade the waste faster and effectivelly. One way to degrade the waste of POEFB is using enzymatic reaction, with the help of cellulolytic microorganisms. Based on previous results, it is clear that five of cellulolytic molds (VTM1, VTM5, VTM6, VM9, and VT12) have significant responsible in vermicomposting process of palm oil empty fruit bunches (Yuniar, 2013), however no further study to elucidate these enzymes. In this study, an isolate VTM1 had been selected as a source for cellulase production, characterisation, and purification.

\section{MATERIALS AND METHODS}

\section{Microorganism Used}

Five isolates of mold namely VTM1, VTM5, VTM6, VM9, and VT12 from previous investigation has been used in this research.

\section{Growth Analysis}

This step was done by counting the isolates spores which inoculated to PDA, incubated for $1-7$ days in $30^{\circ} \mathrm{C}$. The spore were counted everyday with Haemacytometer.

\section{Preparation of Crude Enzyme}

All isolates were cultured in POEFB medium, containing $0.1 \%$ pepton, and incubated for 1-7 days on incubator at $37^{\circ} \mathrm{C}$. Enzyme harvested daily (1-7 days) with $20 \mathrm{ml}$ distilled water containing $1 \% \mathrm{NaCl}$ and $0.01 \%$ sodium azide. Each culture was centrifuged at 4,000 rpm for $10 \mathrm{~min}$. The clear supernatants were collected as extracellular cellulase preparations.

\section{Cellulase Assay}

Cellulase activity was quantified ( $\mu \mathrm{g} / \mathrm{ml} / \mathrm{min}$.) from reducing-end of sugars produced in hydrolysates when of CMC or POEFB substrate used. To quantify of sugars produced, the Somogyi-Nelson method was employed. The cellulase activity was determined by incubating the enzyme $(0.5 \mathrm{ml})$ in $0.5 \% \mathrm{CMC}(0.5 \mathrm{ml})$ and $0.5 \%$ POEFB substrate in $0.02 \mathrm{M}$ acetate buffer, $\mathrm{pH} 5.0$ at $37^{\circ} \mathrm{C}$ for $2 \mathrm{~h}$. The reaction was terminated by the addition of $0.5 \mathrm{ml}$ Somogyi reagent and heated for $15 \mathrm{~min}$ in boiling water. The solution was cooled down to room temperature and $0.5 \mathrm{ml}$ Nelson reagent was added. The resulting solution then diluted with distilled water $(2.5 \mathrm{ml})$ and measured at optical density (OD) $500 \mathrm{~nm}$ against the blank. To calculate of sugar content in hydrolysate, the standard curve with known glucose concentration was used.

\section{Enzyme Purification \\ Ammonium Sulfate Precipitation}

The proteins in the crude preparation were precipitated by the addition of solid ammonium sulfate to $70 \%$ saturation. The precipitate was allowed to form at $4^{\circ} \mathrm{C}$ and was collected by centrifugation at 12,000 at $4{ }^{\circ} \mathrm{C}$ for $20 \mathrm{~min}$. The precipitate was re-dissolved in 10 $\mathrm{ml}$ of $0.02 \mathrm{M}$ acetate buffer, $\mathrm{pH}$ 5.0.

\section{Gel Filtration on Sephadex G-100}

The enzyme concentrate obtained from ammonium sulfate precipitation was redissolved in minimal amount of buffer and dialyzed for $24 \mathrm{~h}$ against $0.02 \mathrm{M}$ sodium phosphate buffer, pH 5.0 containing with changes of the buffer per 4 hour. Remaining debris was removed by centrifugation and the supernatant was slurry loaded on the prepared Sephadex 


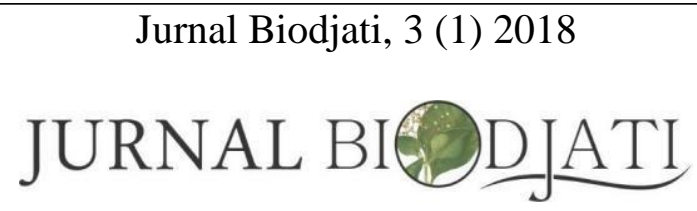

http://journal.uinsgd.ac.id/index.php/biodjati

G-100 column $(2.5 \times 25.0 \mathrm{~cm})$ and equilibrated with $0.02 \mathrm{M}$ acetate buffer, $\mathrm{pH}$ 5.0. The elution was done at a flow rate of $5 \mathrm{ml} / 23$ minutes. The protein concentration in every fraction was monitored at $280 \mathrm{~nm}$ and the cellulase activity was assayed using the procedure above. Fractions with cellulase activity were pooled and was stored at $4{ }^{\circ} \mathrm{C}$ for the next purification step.

\section{Purification by Ion Exchange Chromatog- raphy on DEAE Cellulofine A-500}

DEAE Cellulofine A-500 column was packed into acolumn $(2.5 \times 25 \mathrm{~cm})$. The peaks with highest cellulose activity from the gel filtration step were applied to the column. The column was equilibrated with 3 bed volumes of $0.02 \mathrm{M}$ acetate buffer, $\mathrm{pH}$ 5.0. The column was washed to remove all unbound proteins and a stepwise concentration of $0,0.1,0.2,0.3$, and $0.5 \mathrm{M} \mathrm{NaCl}$ in $0.02 \mathrm{M}$ acetate buffer $\mathrm{pH}$ 5.0 was used to elute any bound proteins. Fractions $(5 \mathrm{ml})$ were collected at a flow rate of $5 \mathrm{ml} / 5$ minutes. The elution was monitored for protein concentration at $280 \mathrm{~nm}$ and was also assayed for enzyme activity. Fractions containing cellulose activities were pooled together and stored at $4^{\circ} \mathrm{C}$

\section{Thin Layer Chromatography (TLC)}

The enzymatic hydrolysis product was analyzed by TLC on a silica gel plate (silica gel 60 F254). Butanol : ethanol : chloroform:ammonia $(4: 7,5: 4: 8)$ was employed as a solvent system. Sulphuric acid was used for detection. The spots were dried by heating at $170^{\circ} \mathrm{C}$. All experiments were carried out at room temperature.

\section{Effect of $\mathrm{pH}$ and temperature on cellulase activity}

In order to analyze the stability of the cellulase at different $\mathrm{pH}$ values, the purified enzyme was incubated at $37^{\circ} \mathrm{C}$ in $20 \mathrm{mM}$ acetate buffer ( $\mathrm{pH} 3$ to 5.5) and phosphate buffer ( $\mathrm{pH} 5.5$ to 8.5). The remaining activity of each sample was measured after 4 hours of incubation. For measuring its thermal stability, the purified cellulase was incubated in $20 \mathrm{mM}$ acetate buffer $\mathrm{pH} 4$ at $30^{\circ} \mathrm{C}$ to $60^{\circ} \mathrm{C}$. Remaining activity was measured after for 4 hours of incubation. The effects of $\mathrm{pH}$ and temperature on the optimum activity of enzyme were also measured in series $\mathrm{pH}$ and temperature range as mentioned above, using 1\% CMC with 2 hours incubation at $37^{\circ} \mathrm{C}$.

\section{RESULT AND DISCUSSION}

\section{Exponential Phase Analysis}

Based on the pattern of growth over 7 days, the adaptation phase occurs on day 0 to day 1 . It was characterized by the absence of an increase in the number of spores during that time. Adaptation phase is a phase adjustment of microorganisms to growth media. Logarithmic phase for mold isolates VTM1, VTM5, VM9 and VT12 occurred on the third day which was marked by an increase in the number of spores in each isolate mold, while the VTM6 occurred on the fourth day.

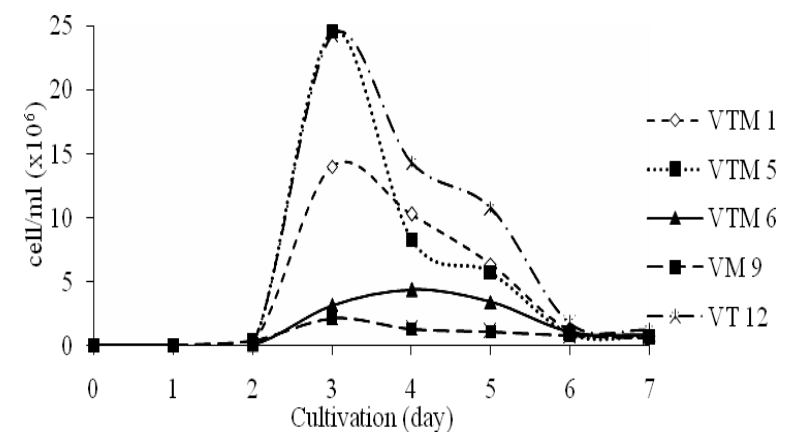

Figure 1. Growth curve isolates

\section{Isolate Selection}

Isolate selection used to choose one of mold isolate that has highest activity. 


\section{Jurnal Biodjati, 3 (1) 2018

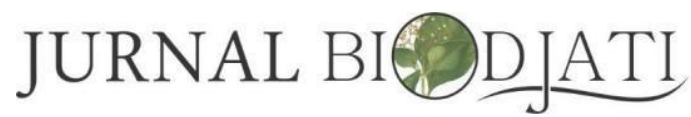

http://journal.uinsgd.ac.id/index.php/biodjati

Table 1. Measurement of Enzyme Activity with CMC and POEFB Substrates

\begin{tabular}{|c|c|c|c|c|c|c|}
\hline \multirow{3}{*}{ Isolate } & \multirow{2}{*}{\multicolumn{2}{|c|}{$\begin{array}{c}\text { Cellulase Activity Index } \\
*)\end{array}$}} & \multicolumn{4}{|c|}{ Enzyme Activity } \\
\hline & & & \multicolumn{2}{|c|}{$\mathrm{CMC}(5 \%)$} & \multicolumn{2}{|c|}{ POEFB $(5 \%)$} \\
\hline & $\mathrm{CMC}$ & TKKS & $\mu \mathrm{g} / \mathrm{ml}$ & $\mathrm{U} / \mathrm{ml}$ & $\mu \mathrm{g} / \mathrm{ml}$ & $\mathrm{U} / \mathrm{ml}$ \\
\hline VTM1 & 3.12 & 3.65 & 71.33 & 4.13 & 34.28 & 3.97 \\
\hline VTM 5 & 8.7 & 5.4 & 14.42 & 0.83 & 22.57 & 2.61 \\
\hline VTM 6 & 2.7 & 5 & 18.33 & 1.06 & 25.03 & 2.90 \\
\hline VM 9 & 1.17 & 1.66 & 27.50 & 1.59 & 19.51 & 2.26 \\
\hline VT 12 & 3.5 & 6 & 15.25 & 0.88 & 24.66 & 2.85 \\
\hline
\end{tabular}

*)Adapted from Yuniar (2013)

VTM1 readily hydrolyzed 5\% CMC and 5\% POEFB substrate and released reducing sugar 71.33 and $34.28 \mu \mathrm{g} / \mathrm{ml}$. Based on this results, the cellulase produced by VTM1 was selected as a source cellulase for purification. As shown at Table 1, the highest activity of cellulase produced by VTM1 when $5 \% \mathrm{CMC}$ either 5\% POEFB used.

\section{Enzyme Purification}

Crude enzyme obtained from optimum cultivation was collected and purified. For the first step, the crude enzyme was brought to $70 \%$ of saturated ammonium sulfate, precipitated by centrifugation at $12000 \mathrm{rpm}$ for 20 minutes, followed by dialysis on cellulose tube (10KDa pores) using $20 \mathrm{mM}$ acetate buffer at $\mathrm{pH} 5$ to remove remaining ammonium sulfate. After dialysis, the concentrated enzyme was loaded onto open column containing Sephadex G-100 pre-equilibrated with the same buffer. The elution profile is showed in figure 2 .

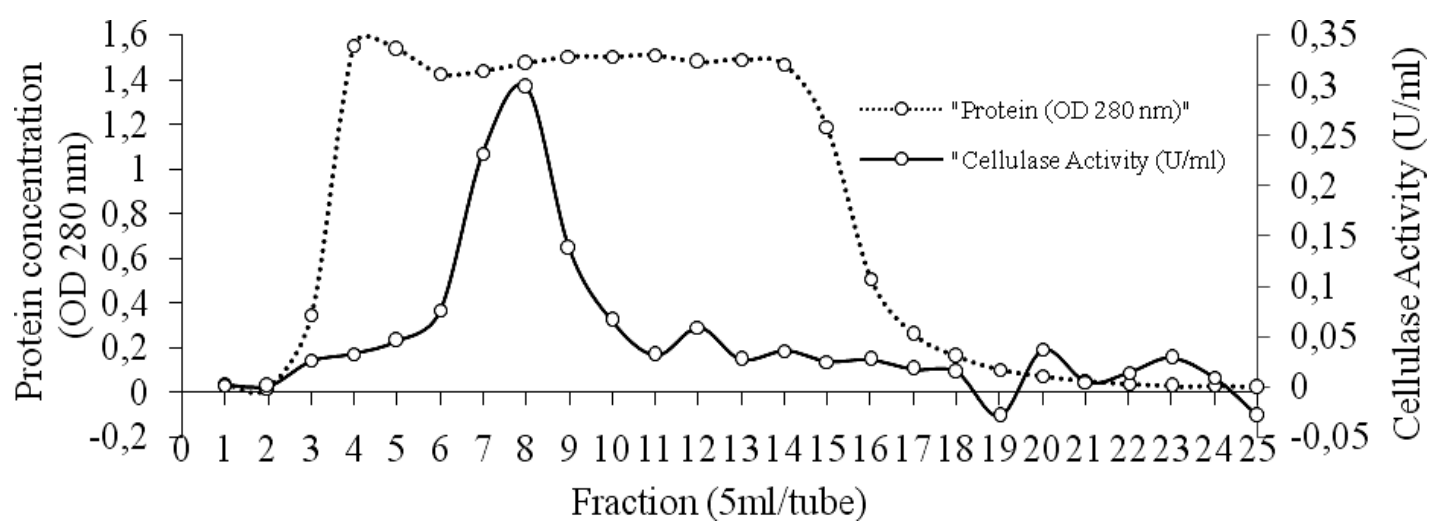

Figure 2. Elution profile of partially purified cellulase from VTM1 (Aspergillus sp.) on Sephadex G100 column. The cellulase activity was determined in each fraction by the appearance of reducing end group in solution of CMC.

Finally, an ion exchange chromatography on DEAE Cellulofine A-500 was used to obtain purified cellulose. DEAE cellulose preequilibrated with the same buffer. For the frac- tionation, the column was eluted using acetate buffer with the gradient $0-0.5 \mathrm{M} \mathrm{NaCl}$. The active fractions were pooled and stored at $4^{\circ} \mathrm{C}$. The elution profile is showed in figure 3 . 


\section{JURNAL BIODJATI}

http://journal.uinsgd.ac.id/index.php/biodjati

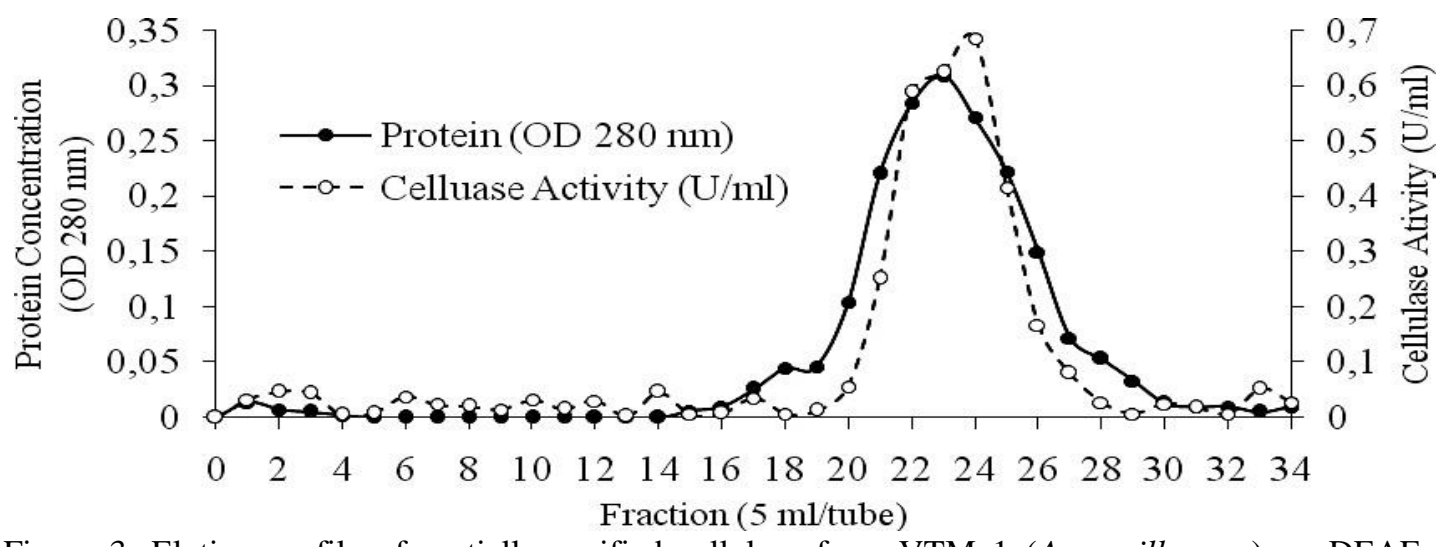

Figure 3. Elution profile of partially purified cellulase from VTM 1 (Aspergillus sp.) on DEAECellulofine A-500 column. The cellulase activity was determined in each fraction by the appearance of reducing end group in solution of CMC.

The results of the purification of the summarized in Table 2. cel- lulase from VTM 1 (Aspergillus sp.) are

$\frac{\text { Table 2. Summary of Purification of Cellulase from VTM } 1 \text { (Aspergillus sp.) }}{\text { Enzyme }}$

Purification Step $\quad$ Activity $(\mathrm{U} / \mathrm{ml})$ $\begin{array}{lll}\text { Total Ac- } & \text { Protein } & \text { Activity } \\ \text { tivity }(\mathrm{U}) & \end{array}$ $(\mathrm{mg} / \mathrm{ml})$

(U/mg)

$\begin{array}{cc}\text { Yield } & \text { Purification } \\ (\%) & \text { Fold }\end{array}$

\begin{tabular}{lcccccc} 
Crude enzyme & 14.70 & 1470.43 & 5723.40 & 0.26 & 100 & 1 \\
Ammonium sulfate & 16.17 & 404.32 & 3006.25 & 0.13 & 27.50 & 0.52 \\
Sephadex G-100 & 5.04 & 151.17 & 19.32 & 7.82 & 10.28 & 30.45 \\
DEAE Cellulofine & 4.74 & 189.47 & 6.86 & 27.62 & 12.89 & 107.50 \\
\hline
\end{tabular}

As shown in Table 2, after loaded into ion exchange chromatography on DEAE Cellulofine A-500, the purified cellulase was obtained. The yield and purification fold were $12.89 \%$ and 107.50 , respectively. The culture filtrates of VTM 1 (Aspergillus sp.) expressed cellulase which was subsequently purified to homogeneity. The gel filtration yielded only one peak with specific activities of $27.62 \mathrm{U} / \mathrm{mg}$ protein respectively. These values were greater than the values obtained for cellulase from $\mathrm{As}$ pergillus niger (4.2x10-3 U/mg) (Hurstet et al.,
1977) and lower than Aspergillus oryzae (43.9 U/mg) (Yamane et al., 2002).

\section{Cellulase Characterization}

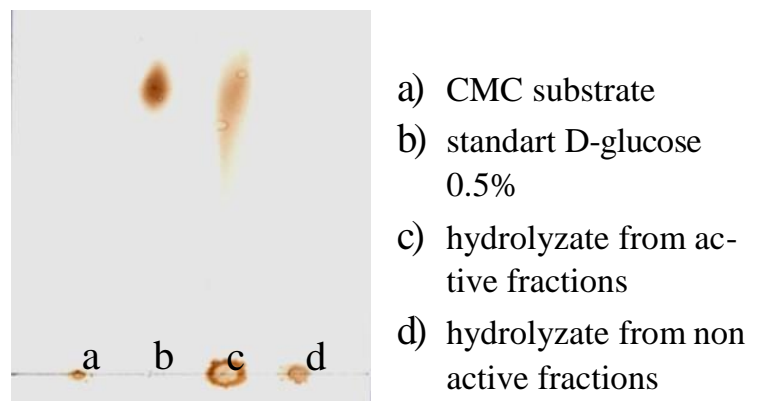

Figure 4. TLC Analysis of hydrolyzates 


\section{Jurnal Biodjati, 3 (1) 2018

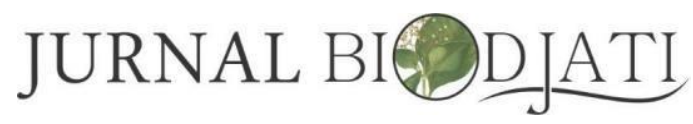

http://journal.uinsgd.ac.id/index.php/biodjati

The spot on TLC show the presence of monosaccharides from $\mathrm{CMC}$ hydrolysis by cellulase enzymes. When compared with $0.5 \%$ glucose standard can be seen that the monosaccharide is glucose. When compared with the results of the inactive fraction, showed that purified enzyme can produce monomers glucose. This evidence proved that the purified cellulase easily released glucose when 5\% CMC as substrate as shown by TLC analysis.

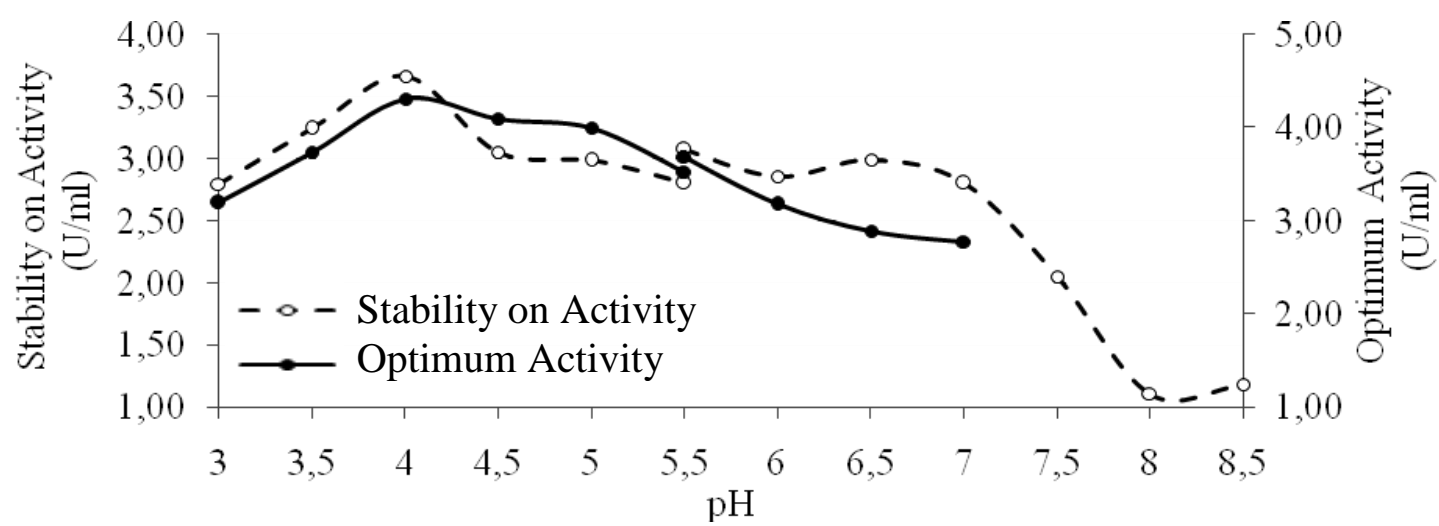

Figure 5. Effect of pH on optimum activity and stability of purified cellulase

As shown on Figure 5, the cellulase had optimum activity at $\mathrm{pH} 4$ and the stability at $\mathrm{pH} 3$ to 5. Furthermore, as shown on Figure 6, the cellulase had optimum activity at $45^{\circ} \mathrm{C}$ and stability at 30 to $50^{\circ} \mathrm{C}$, correspondingly.

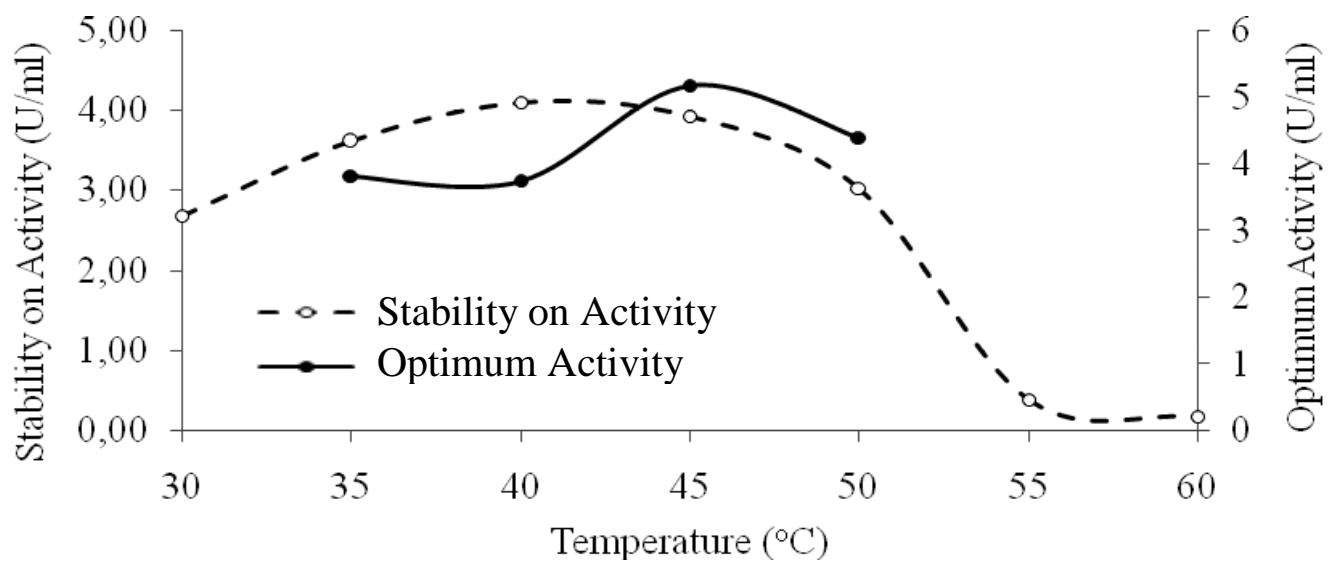

Figure 6. Effect of temperature on optimum activity and stability of purified cellulase

This result is similar to researches of Begum \& Absar (2009) and Yamane et al.,. (2002) with Aspergillus oryzae; Devi \& Kumar (2012) and Hurst et al., (1977) with Aspergillus niger; and Andrade et. al, (2011) with Trichoderma, sp., which the range of activity of cellulase enzymes from fungi at $\mathrm{pH} 3$ -
7,5 and at a temperature of $40-60^{\circ} \mathrm{C}$, cellulase enzymes undergo denaturation at $\mathrm{pH}$ below 2.5 and above 7.5, and the temperature is below $30^{\circ} \mathrm{C}$ and above $80^{\circ} \mathrm{C}$. At higher or lower $\mathrm{pH}$ and temperature than the stabil, enzyme activity decreases because of denaturation. 


\section{JURNAL BIODJATI}

http://journal.uinsgd.ac.id/index.php/biodjati

\section{REFERENCES}

Andrade, J. P., Bispo, A. S. D. R., Marbach, P. A. S., \& do Nascimento, R. P. (2011). Production and Partial Characterization of Cellulases from Trichoderma sp. IS-05 Isolated from Sandy Coastal Plains of Northeast Brazil. Enzyme Research, 1-7.

Ariffin, H., Abdullah, N., Kalsom, M. S. U., Shirai, Y., \& Hassan, M. A. (2006). Production and Characterisation of Cellulase by Bacillus pumilus EB3. International Journal of Engineering and Technology, 3(1), 47-53.

Bakare, M. K., Adewale, I. O., Ajayi, A., \& Shonukan, O. O. (2005). Purification and characterization of cellulase from the wild-type and two improved mutants of Pseudomonas fluorescens. African Journal of Biotechnology, 4(September), 898-904.

Begum, M. F., \& Absar, N. (2009). Purification and Characterization of Intracellular Cellulase from Aspergillus. Mycobiology, 37(2), 121-127.

Devi, M. C., \&Kumar, M. S. (2012). Production, Optimization and Partial Purification of Cellulase by Aspergillus niger Fermented with Paper and Timber Sawmill Industrial Wastes. Journal of Microbiology and Biotechnology Research, 2(1), 120-128.

Fitri, A. V, Restiawaty, E. \& Moeis, M. R. (2017). Extracellular $\quad \beta$-Glucosidase Production from bglp15.2 Gene Carrying Inulinase Signal Peptide in Saccharomyces cerevisiae BY4741. Jurnal Biodjati, 2(2), 95-106.

Hayati, P. D. (2010). Pengaruh Pemberian Tandan Kosong Kelapa Sawit (TKKS) terhadap Sifat Biologi Tanah dan Produksi Kelapa Sawit (Elaeis guinensis Jack). Riau.
Hurst, B. P. L., Nielsen, J. A. N., Sullivan, P. A., \& Shepherd, M. G. (1977). Purification and Properties of a Cellulase from Aspergillus niger. Biochem, J, 165, 33-41.

Kanti, A. (2005). Actinomycetes Selulolitik dari Tanah Hutan Taman Nasional Cellulolytic Actinomycetes isolated from soil in Bukit Duabelas National Park, Jambi. Biodiversitas, 6(2), 85-89.

Kim, C., \& Kim, D. (1995). Purification and specificity of a (Avicelase II ) resembling excellobiohydrolase from Bacillus circulans. Enzyme and Microbial Technology, 17, 248-254.

Masfufatun. (2009). Isolasi dan Karakterisasi Enzim Selulase. Surabaya.

Muzakhar, K., Masruroh, Siswoyo, Winarsa, R., Sutoyo, 2017, Sugar-rich hydrolysates of palm oil empty fruit bunch production through two step solid state fermentations and its conversion to ethanol, Advanced Science Letters, 23(3), pp. 2533-2535 .

Muzakhar, K., Sutoyo, Saragih, A.B., 2015, Phosphate solubilizing bacteria adaptive to vinasse, Journal of Mathematical and Fundamental Sciences 47(2), pp. 219225.

Yamane, Y., Fujita, J. I. N., Izuwa, S., Fukuchi, K., Shimizu, R., Hiyoshi, A., \& Fukuda, H. (2002). Properties of Cellulose-Degrading Enzymes from Aspergillus oryzae and Their Contribution to Material Utilization and Alcohol Yield in Sake Mash Fermentation. Journal of Bioscience and Bioengineering, 93(5), 479-484.

Yuniar, W. (2013). Proses, Skrining dan Identifikasi Kapang Selulolitik pada Proses Vermikomposting Tandan Kosong Kelapa Sawit (TKKS). Skripsi. Universitas Jember. 